\title{
3 Research Soure \\ Configuration of Flowsheet and Reagent Dosage for Gilsonite Flotation Towards the Ultra-Low-Ash Concentrate
}

Ataallah Bahrami ( $\triangle$ A.bahrami@urmia.ac.ir)

Urmia University

Fatemeh Kazemi

University of Kashan

Mirsaleh Mirmohammadi

University of Tehran

Yousef Ghorbani

Luleå University of Technology

Saghar Farajzadeh

Urmia University

\section{Research Article}

Keywords: gilsonite, ultra-low ash, mineralogy, flotation, collector, frother, depressant, processing flowsheet.

Posted Date: April 21st, 2021

DOl: https://doi.org/10.21203/rs.3.rs-422431/v1

License: (1) This work is licensed under a Creative Commons Attribution 4.0 International License.

Read Full License

Version of Record: A version of this preprint was published at Scientific Reports on July 29th, 2021. See the published version at https://doi.org/10.1038/s41598-021-95074-8. 


\section{Abstract}

Gilsonite is a natural occurrence of bitumen and consists of a complex structure of organic compounds. Gilsonite has a wide variety of applications in the industry, including the manufacture of electrodes, paints and resins, as well as the production of asphalt and roof-waterproofing material. Ash content of gilsonite is a determining parameter for its application in some industries (e.g., ash content $<5 \%$ as an additive in drilling fluids, Resins). In this study, a process mineralogy approach used in order to design an optimal flotation circuit for the production of gilsonite concentrate with ultra-low ash content $(<5 \%)$ from gilsonite ore with an average ash content of $15 \%$. According to mineralogical studies, carbonates and clay minerals are the main associated impurities (more than 90 vol.\%). Furthermore, sulfur was observed in two forms of mineral (pyrite and marcasite) and organic in the structure of gilsonite. Most of these impurities are interlocked with gilsonite in size fractions smaller than $105 \mu \mathrm{m}$. In addition, the size of $+105 \mu \mathrm{m}$ to $420 \mu \mathrm{m}$ has a higher pure gilsonite (approximately $90 \%$ ) than other size fractions. The effect of different reagent regime on the production of low ash content concentration in gilsonite flotation are investigated. Based on the results, $400 \mathrm{~g} /$ ton of kerosene collector led to the production of a concentrate with the lowest amount of ash $(6.36 \%)$ in the rougher stage. In addition, the highest amount of recovery $(80.83 \%)$ were obtained in gilsonite flotation with kerosene collector. The use of depressants in the rougher stage increased the gilsonite recovery by $3.5 \%$ and slightly reduced the ash content (less than $0.20 \%$ ) of gilsonite concentrate. In general, gilsonite flotation with $400 \mathrm{~g} /$ ton kerosene collector, $100 \mathrm{~g} / \mathrm{ton}$ from a mixture of sodium silicate, tannic acid, sulfuric acid and sodium cyanide depressants, and the use of $100 \mathrm{~g} /$ ton MIBC resulted in the production of a concentrate with the lowest amount of ash (6.36\%) in the rougher flotation stage. Cleaner and recleaner flotation for the rougher flotation concentrate resulted in a product with an ash content of $4.89 \%$ and recovery of $86.75 \%$. Due to the interlocking of gilsonite with impurities in size fractions smaller than $105 \mu \mathrm{m}$, it is better to re-grinding the concentrate of rougher stage then flotation done in the cleaner and recleaner stages. Finally, flowsheet has been proposed to produce gilsonite with the least ash.

\section{Introduction}

Gilsonite is a natural occurrence of bitumen, which contains a complex structure of organic components [1]. The physical and chemical properties of gilsonite make it an intermediate substance between coal (fossil fuel) and bitumen (a petroleum product). Though the appearance of gilsonite looks alike to hard coal or asphalt, its chemical properties are significantly different. According to the chemical analysis [1] of the gilsonite structure, carbon-13 NMR $\left({ }^{13} \mathrm{C}\right.$ Nuclear Magnetic Resonance) showed carbon aromaticity (with a yield of $27 \%$ ) in the gilsonite structure. Some parts of gilsonite have been seen as single rings or groups of molten rings. Pyrroles make up about $50 \%$ of the aromatic carbon of gilsonite. In addition, based on CP-MAS isotopes of carbon and nitrogen, most of $\mathrm{N}$ is pyrrolic. In the structure of gilsonite, aromatic rings have replaced with alkyl chains. Furthermore, specific functional groups such as $\mathrm{CCH}_{3}$, $\mathrm{CCH}_{2}$, and $\mathrm{C}=\mathrm{CH}_{2}$ have been identified via advanced techniques of NMR. Based on obtained results from 
advanced NMR and mass spectrometry (MS), the structure of gilsonite proposed to be as a mixture of pyrrolic and molten aromatic rings that replaced with aliphatic chains [1].

Based on the proposed structure for gilsonite, this material is soluble in aromatic and aliphatic solvents as well as pitch; therefore, gilsonite is often used to harden softer oil products. Most of gilsonite have been used in dark-colored printing inks and paints, drilling muds, waterproofing and undercoating applications, and other uses identical to crude asphalt and etc. [2]. For such applications gilsonite mostly are used without any processing operations and accounting ash content. Gilsonite ash sometimes called gilsonite combustion residuals, which is produced from the burning of gilsonite [3]. For example, gilsonite with ash value about $10-15 \%$, is used in asphalt for increased stability. Gilsonite with a low ash percentage $(<5 \%)$ is used in some specific industrial applications as presented in Table $1[4,5]$.

Gilsonite in these applications must has a special atomic ratio of $\mathrm{H} / \mathrm{C}, \mathrm{O} / \mathrm{C}, \mathrm{C} / \mathrm{N}, \mathrm{S} / \mathrm{C}$ and high purity or low ash (usually less than $5 \%$ ). For this purpose, in gilsonite production, the removal of impurities (in accordance with the standards of consumer industries) is carried out in two stages of extraction and processing. In this regard, the extraction of gilsonite deposits is based on the ash content of the deposit and is conducted selectively. It is worth noting that gilsonite mineralization occurs mainly in massive forms and lens-shaped masses at the boundary of marne and gypsum units, as well as in faults, fractures, and even karst cavities. Among them, mineralization in the interference of gypsum and marl units has the highest volume of valuable minerals that are usually extracted selectively by open-pit method. After selective extraction, concentration processes are performed to remove the associated impurities in order to produce the industry-required gilsonite. 
Table 1

Some example of specific industrial applications for gilsonite with a low ash (<5\%).

\section{Industrial Brief description applications}
Gilsonite
It is extensively employed as the primary carbon black wetting component in black
Resin news inks and headset and gravure inks. Gilsonite resin contends favorably with petroleum-based hydrocarbon resins, phenolic resins, and metal resonates, all of which can supplement or substitute to some extent. Several concentrations of gilsonite resin are utilized to fabricate low-rub-off news inks with greater gloss and tack properties.
Gilsonite It helps reduce imperfections due to the rapid reaction between the silica sand mold foundry and the oxidized surface of molten iron, improve sand peel from casting at shakeout, sand $\quad$ produce smoother, cleaner casting surface and minimize imperfections, casting losses, scrap.
Gilsonite as It is an ingredient in many additives used in the production of steel. Gilsonite fulfills an additive many roles as a part of steel creating additives. First, chemical reactions that will in steel move the impurities to the molten scum layer will take place. Next, the volitiles that industry are given off are high in lustrous carbon, which is able to more reduce the Iron oxide to steel. Finally, the portion of gilsonite that is not volatilized could be a terribly extremely structured asphaltene structure that is nearly pure carbon.

Gilsonite as an additive in drilling fluids It has long been used in oilfields as a fluid loss additive in drilling fluids. Gilsonite has been utilized to fight borehole instability complications, offer lubricity particularly in greatly diverged holes, and lately, as a bridging instrument to contest differential pressure sticking and deliver a less invasive coring fluid.

Gilsonite in production of Gilsonite contains high amounts of carbon used in the manufacturing of anode electrodes for the aluminum extraction.

aluminum

anodes

Identifying the types of gangue minerals associated with gilsonite and characteristics such as particle size and type of interlocking can have a significant impact on determining and optimizing its concentration processes. Due to the mineralization type of gilsonite deposits, the associated gangues include carbonate mineral mainly of calcite and dolomite, shale, mar1, fine sulfate particles such as gypsum, fine silica particles and opaque minerals. Sulfur is also found in gilsonite structure in both inorganic compounds and organic compounds in the form of pyrite and marcasite and gypsum minerals. Gangue minerals particles vary in size from about a few microns to several millimeters. The distribution of gangue particles varies from deposit to deposit; however, in general, carbonate and shale compounds form the main gangues [3]. Due to the type of impurities and their distribution in the matrix of bituminous materials, it will be possible to produce high purity (low ash) gilsonite by performing processes such as comminution (in order to obtain the appropriate liberation degree) and flotation. The non-oxidized surface of gilsonite is naturally hydrophobic since it is composed of non-polar hydrocarbons. While ash materials associated with gilsonite, are composed of strong polar compounds, so water is absorbed to the surface of these materials and they do not float. This fundamental difference in structure will facilitate the separation of gilsonite by flotation technique $[3,6,7]$. 
The aim of this study is to design a flotation circuit to produce gilsonite with the lowest amount of ash (< $5 \%$ ), and in this regard, the distribution of impurities has been studied in terms of type and particle size in gilsonite deposits. The degree of particle liberation and the appropriate comminution conditions for gilsonite particles are then determined. In the next step, the type and amount of different chemicals in different stages has been determined for the gilsonite flotation process. The effect of combination (interaction) of chemical reagents including collector, frother and depressant are also studied in order to produce a concentrate with the lowest ash content. Finally, a processing circuit for the production of low ash gilsonite concentrate has been designed based on mineralogical studies and the results of flotation experiments.

\section{Materials And Method}

Holding about $15 \%$ (15 million tons) of the world's gilsonite reserves, Iran has the third-largest reserve of this mineral. The natural bitumen deposits of Iran lie along the main Zagros fault with a NW-SE direction. These deposits are found in the folded Zagros belt, which is $200-250 \mathrm{~km}$ wide. Gilsonite reserves of Iran are generally located in the west of the country and Kermanshah province holds about $75 \%$ of gilsonite reserves $[8,9]$. The samples studied in this research are collected from gilsonite mines located in the western part of Kermanshah province and near of Gilan-e-Gharb and Qasr-e-Shirin cities. It should be noted that there are 25 operating gilsonite mines and 153 exploration licenses in this area.

\section{2-1 Physical and chemical characterization of gilsonite}

Characterization of the sample will lead to an appropriate design of the experiment and better results from the operation. In this regard, after bulk sampling (with mass about $100 \mathrm{~kg}$ ) from gilsonite mines in the west of Kermanshah province and preparation of the sample by coning and quartering method, comminution processes were performed by jaw crusher, roller crusher and ball mill to the particle size of smaller than $2 \mathrm{~mm}$. In order to determine the physical and chemical properties of gilsonite, tests were performed on the representative sample, the results of which are shown in Tables 2 and 3 . For these propose, Moisture, fixed carbon, and density measured by a standard test method for the analysis sample of coal and coke. LECO analyzer (CS844) was used to measure the concentration of elements in the gilsonite sample. It is worth mentioning that LECO analysis is a reliable method for determining the concentration of elements within an organic sample, including Carbon, Hydrogen, Nitrogen, Oxygen, and Sulfur [3]. According to Table 2, the amount of gilsonite ash is $15 \%$, which needs to be processed in order to be used in industries such as paint, resin, etc. In addition, the amount of carbon in the sample is less than the standard values $(>80 \%)$ and the amount of sulfur is higher than the standard $(<0.3 \%)$. Table 3 shows the chemical composition of the gilsonite sample determined using X-ray fluorescence (XRF). Based on the obtained results, $\mathrm{CaO}$ and $\mathrm{SiO}_{2}$ with values of 5.38 and $2.10 \%$, respectively, are the major gangue compounds in the gilsonite sample. With respect to the grade of elemental sulfur, $\mathrm{CaO}$ and $\mathrm{Fe}_{2} \mathrm{O}_{3}$ (XRF analysis - Table 3), it can be said that most of the $S$ of the sample are in the form of gypsum. 
Table 2

Typical physical properties and characteristics of the gilsonite

\begin{tabular}{|c|c|c|c|}
\hline \multicolumn{2}{|c|}{ General information } & \multicolumn{2}{|l|}{ Properties } \\
\hline color & Brown - Black & Specific gravity (at $25^{\circ} \mathrm{C}$ ) & 1.20 \\
\hline Color index & Natural black 6 (NBk 6) & Moisture & $0.80 \%$ \\
\hline Chemical name & Bitumen & Ash & $15 \%$ \\
\hline \multirow[t]{4}{*}{ Chemical formula } & $\mathrm{C}_{28} \mathrm{H}_{16} \mathrm{C}_{18} \mathrm{O}_{8}$ & Bulk density & $40 \mathrm{ibs} . / \mathrm{ft}^{3}$ \\
\hline & & Hardness (Moh) & 2 \\
\hline & & Refractive index & $1.59-1.64$ \\
\hline & & Fusing (softening) point $\left({ }^{\circ} \mathrm{C}\right.$ ) & $161-230$ \\
\hline
\end{tabular}

Table 3

Elemental compositions of the gilsonite

\begin{tabular}{|c|c|c|c|c|c|c|c|c|c|}
\hline \multicolumn{10}{|c|}{ XRF Analysis (wt.\%) } \\
\hline $\mathrm{SiO}_{2}$ & $\mathrm{Al}_{2} \mathrm{O}_{3}$ & $\mathrm{Fe}_{2} \mathrm{O}_{3}$ & $\mathrm{CaO}$ & $\mathrm{Na}_{2} \mathrm{O}$ & $\mathrm{K}_{2} \mathrm{O}$ & $\mathrm{MgO}$ & $\mathrm{TiO}_{2}$ & $\mathrm{MnO}$ & $\mathrm{P}_{2} \mathrm{O}_{5}$ \\
\hline 2.10 & 0.49 & 0.75 & 5.38 & 0.16 & 0.16 & 0.01 & 0.04 & 0.001 & 0.04 \\
\hline \multicolumn{10}{|c|}{ Element Analysis (LECO) wt.\% } \\
\hline \multicolumn{2}{|c|}{ Carbon } & \multicolumn{2}{|c|}{ Hydrogen } & \multicolumn{2}{|c|}{ Nitrogen } & \multicolumn{2}{|c|}{ Oxygen } & \multicolumn{2}{|l|}{ Sulfur } \\
\hline \multicolumn{2}{|c|}{73.80} & \multicolumn{2}{|l|}{7.40} & \multicolumn{2}{|l|}{0.80} & \multicolumn{2}{|l|}{3.10} & \multicolumn{2}{|l|}{6.98} \\
\hline
\end{tabular}

\section{2-2 Mineralogical characterization}

In order to identify the form of the interlocking of gangue minerals with gilsonite, particle size and their degree of liberation, microscopic studies were performed on polished and thin sections using the Leitz microscope model SM-LUX-POL. Based on petrographic studies, the main constituent is bituminous materials in which silicate and non-silicate impurities are observed. Silica as quartz, sulfur in the form of iron sulfide (pyrite-marcasite), carbonate and clay minerals (Fig. 1).

In order to determine the liberation degree of gilsonite, a representative sample was first prepared and crushed to a size of smaller than $3.35 \mathrm{~mm}$. The gilsonite sample was then classified using a series of screens according to the ASTM standard. Optical microscopic studies have been used to determine the degree of liberation as well as the interlocking of gilsonite particles and gangues. For this purpose, 3 standard polished sections were prepared and the impurities minerals were determined by microscopic studies. Afterward, digital microscopic images were taken from each thin section. 
Due to the fact that gilsonite is naturally hydrophobic and its associated impurities (carbonates and shales) are hydrophilic, the flotation method has been used to reduce the ash content and produce highpurity gilsonite. In order to perform flotation experiments, different reagents including collectors, frothers and depressants (used in the rougher stage) were studied. The specifications and conditions of the experiments are given in Table 4. In each experiment, after preparing the pulp with a weight percentage of $10 \%$ and conditioning time (The time of removing impurities from the surface of gilsonite particles and mixing the pulp) of 10 minutes, it was mixed in the cell for two minutes with a rotor speed of $1250 \mathrm{rpm}$. The collector was then added to the pulp and mixed for two minutes. In the next step, the frother was added to the pulp and continued to mix for 30 seconds. Then, the air was blown into the cell and the concentrating test was performed. During this period, a constant flow of water was added to keep the pulp level inside the cell constant and the concentrate was collected at a constant speed. Finally, all products, including concentrates and tails, were filtered and dried. They were then weighed and analyzed for ash content. After calculating the amount of ash, flotation recovery was calculated using Eq. 1. Where, $W_{c}$ is concentrate weight, $A_{c}$ is the percentage of concentrate ash, $W_{f}$ is feed weight and $A_{f}$ is percentage of feed ash.

$$
\% R=\frac{W_{c}\left(100-A_{c}\right)}{W_{f}\left(100-A_{f}\right)}
$$

Flotation tests were performed in rougher, cleaner and recleaner stages with similar conditions. Gilsonite flotation experiments have been performed in different conditions of chemical reagents types and concentrations, and the specifications for the experiments are given in Table 5. A total of 11 flotation experiments were performed at the rougher stage. In addition, the effect of cleaner and recleaner flotation stages was studied on two higher-grade (with ash content $<5 \%$ ) concentrate of two rougher flotation experiments, in order to produce the concentrate with minimum ash content.

Table 4. Chemical reagents used and conditions for gilsonite flotation experiments

\begin{tabular}{|c|c|c|c|}
\hline$+75-420(\mu \mathrm{m})$ & $\begin{array}{l}\text { Optimal size } \\
\text { fraction }\end{array}$ & 7 & $\mathrm{pH}$ \\
\hline MIBC & Frothers & 5 & $\begin{array}{l}\text { Solid } \\
\text { weight } \%\end{array}$ \\
\hline kerosene, gas oil, Pine oil & Collectors & 1250 & $\begin{array}{l}\text { Rotor } \\
\text { speed } \\
\text { (rpm) }\end{array}$ \\
\hline 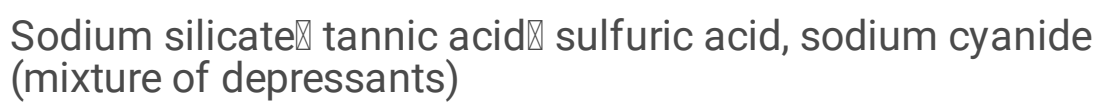 & Depressants & & \\
\hline
\end{tabular}

Table 5. Conditions and specifications of gilsonite flotation experiments based on the type and amount of reagents 


\begin{tabular}{|c|c|c|c|c|c|c|}
\hline \multicolumn{2}{|l|}{ Collector } & \multicolumn{2}{|c|}{ Frother } & \multicolumn{2}{|l|}{ Depressant } & \multirow{2}{*}{$\begin{array}{l}\text { No. of } \\
\text { experiment }\end{array}$} \\
\hline Type & $\begin{array}{l}\text { amount } \\
\text { (g/ton) }\end{array}$ & Type & $\begin{array}{l}\text { amount } \\
\text { (g/ton) }\end{array}$ & Type & $\begin{array}{l}\text { amount } \\
\text { (g/ton) }\end{array}$ & \\
\hline - & - & - & - & - & - & 1 \\
\hline- & - & - & - & $\begin{array}{l}\text { Mixed } \\
\text { depressant }\end{array}$ & 100 & 2 \\
\hline- & - & - & - & $\begin{array}{l}\text { Mixed } \\
\text { depressant }\end{array}$ & 200 & 3 \\
\hline Pine oil & 200 & MIBC & 150 & - & - & 4 \\
\hline kerosene & 400 & MIBC & 150 & - & - & 5 \\
\hline Gas oil & 100 & MIBC & 150 & - & - & 6 \\
\hline kerosene & 400 & MIBC & 100 & $\begin{array}{l}\text { Mixed } \\
\text { depressant }\end{array}$ & 100 & 7 \\
\hline Gas oil & 600 & MIBC & 100 & $\begin{array}{l}\text { Mixed } \\
\text { depressant }\end{array}$ & 100 & 8 \\
\hline kerosene & 400 & MIBC & 100 & $\begin{array}{l}\text { Mixed } \\
\text { depressant }\end{array}$ & 200 & 9 \\
\hline Pine oil & 150 & - & - & $\begin{array}{l}\text { Mixed } \\
\text { depressant }\end{array}$ & 100 & 10 \\
\hline Pine oil & 250 & - & - & $\begin{array}{l}\text { Mixed } \\
\text { depressant }\end{array}$ & 100 & 11 \\
\hline
\end{tabular}

\section{Results And Discussion}

\section{3- 1 Mineralogical composition and degree of liberation}

Gangue materials associated with gilsonite, in the order of abundance are included carbonate compounds mainly calcite and dolomite (91 vol.\%), shale compounds (7 vol.\%), marl (0.9 vol.\%), fine particles of sulfate compounds such as gypsum ( 0.6 vol.\%), fine quartz and opaque minerals (pyrite and marcasite) ( 0.5 vol.\%) with a variable size. These impurities compounds are observed in different size fractions and their frequency ratio is almost constant. In other words, with decreasing particle size, the amount of waste compounds does not change and interlocking between bituminous particles and associated impurities are visible (Fig. 2). Most gangue materials smaller than $50 \mu \mathrm{m}$ are observed in fractions smaller than $105 \mu \mathrm{m}$ interlocked with the valuable mineral. Gilsonite with relatively higher purity are mainly concentrated in the size fraction of 105-420 $\mu \mathrm{m}$. A major part of carbonate and clay gangues, exists in fractions smaller than $105 \mu \mathrm{m}$ (especially $75 \mu \mathrm{m}$ ). According to these studies, most gangue materials (at least $70 \%$ ) have size fraction larger than $150 \mu \mathrm{m}$. The distribution of gangue particles varies 
in size and quantity. Overall, carbonate and clay compounds make up the major gangue of samples (about 98 vol.\%), and other mentioned gangue compounds are rather minor (less than 2\%) (Fig. 3).

Achieving a proper degree of liberation in large size fractions reduces the energy consumption of the grinding process and separates the minerals for a lower cost. Figure 4 shows gilsonite liberation degree in different size fractions. According to Fig. 4, the degree of liberation was determined to be about $110 \mu \mathrm{m}$ considering $80 \%$ liberation of particles. Approximately 25 to $35 \%$ of gilsonite particles are liberated in + 2300 and $+850 \mu \mathrm{m}$ size factions. The reason for no increase in gilsonite liberation degree with decreasing the particles size in $+840 \mu \mathrm{m}$ size fraction is the heterogeneous nature of gilsonite. Gangue minerals particles in 250-420 $\mu \mathrm{m}$ size fraction can be divided into two groups in terms of particle size. The first group is coarse, with a size of $100-200 \mu \mathrm{m}$, and the second group is smaller and most of their particles are smaller than $50 \mu \mathrm{m}$. Approximately 60 to $65 \%$ of the particles are liberated in this size fraction, however as the particle size decreases to $150 \mu \mathrm{m}$, the degree of liberation has reached about $70 \%$. Finally, the degree of liberation for the size factions smaller than $45 \mu \mathrm{m}$ has reached $95 \%$. A portion of the gangue material is mostly seen interlocked with the bituminous material in this size fraction.

\section{3 - 2 Reagent regime in gilsonite flotation}

\section{A) Type and dosage of collector}

According to mineralogical studies and identification of gangue compounds associated with gilsonite, effect of three different non-polar collectors namely pine oil, kerosene, and gas oil were studied on gilsonite flotation. The experiments were performed in the presence of $150 \mathrm{~g} / \mathrm{ton}, \mathrm{MIBC}$ as the frother, $10 \%$ solids, and 10 minutes of conditioning time. As presented in Fig. 5, the ash values of the three tests are close to each other. While according to a study conducted by Bahrami et al. (2019b) the amount of ash in the concentrate of gilsonite flotation test in the state without the use of reagents, is about 13\% [10]. The gas oil collector has led to the production of a concentrate with the lowest ash content, while the highest recovery value belongs to the gilsonite flotation with kerosene collector at $80.83 \%$. Therefore, it can be concluded that the use of $400 \mathrm{~g} /$ ton kerosene and $100 \mathrm{~g} /$ ton gas oil as collectors and MIBC as frother leads to better results compared to pine oil collector (with the dosage of $200 \mathrm{~g} / \mathrm{ton}$ ). Given that gilsonite is naturally hydrophobic, the use of non-polar collectors in gilsonite flotation will increase its recovery rate by floating the interlocked gilsonite particles. It is worth mentioning that none of nonorganic materials or gilsonite ash, including illite, montmorillonite, quartz, gypsum, pyrite, dolomite, calcite, hematite, and shale, are naturally hydrophilic. Therefore, most of the free gangue particles associated with gilsonite are rejected to the tailings stream during rougher flotation stage. Similar studies have confirmed this and indicate that maximum recovery of gilsonite obtained during the rougher flotation stage belongs to kerosene collector and MIBC frother [10].

In order to investigate the effect of kerosene concentration on the grade and recovery of gilsonite flotation, experiments with 400 and $600 \mathrm{~g} /$ ton of kerosene in the presence of $100 \mathrm{~g} /$ ton MIBC as a frother and $100 \mathrm{~g} /$ ton of four different depressants (sodium silicate, acid Tannic, sulfuric acid and sodium cyanide) were performed. A shown in Fig. 6, increasing the concentration of kerosene from 400 to 600 
$\mathrm{g} /$ ton has increased the recovery of gilsonite by $28 \%$. In this case, the ash content has also increased by $2.24 \%$. During complementary experiments, the effect of 150 and $250 \mathrm{~g} /$ ton of pine oil collector concentrations and the use of $100 \mathrm{~g} /$ ton of sodium silicate, tannic acid, sulfuric acid and sodium cyanide depressants were investigated. The results are presented in Fig. 6. A $100 \mathrm{~g} /$ ton increase of pine oil collector has resulted in a $19.7 \%$ increase in recovery and a $0.22 \%$ decrease in the ash content of the flotation concentrate. According to Fig. 6, gilsonite flotation with $400 \mathrm{~g} /$ ton kerosene collector, $100 \mathrm{~g} /$ ton a mixture of sodium silicate, tannic acid, sulfuric acid and sodium cyanide as depressants and the use of $100 \mathrm{~g} /$ ton MIBC has led to the production of concentrate with the lowest amount of ash content $(6.36 \%)$ in the rougher flotation stage.

\section{B) Depressant type and dosage}

In order to investigate the effect of depressants on gilsonite flotation, experiments were performed in two state using sodium silicate - tannic acid - sulfuric acid and sodium cyanide depressants and without depressants. The diagrams of ash content and recovery of these experiments are illustrated in Fig. 7. The use of depressants has increased the recovery of gilsonite (by 3.5\%) and slightly reduced the ash content of the gilsonite concentrate. As shown in Fig. 8, increasing the concentration of the depressant did not significantly reduce ash content in gilsonite concentrate, but the recovery value increased by $5 \%$, by increasing the concentration from 0 to $200 \mathrm{~g} /$ ton. Generally, to depress fine particles of gangue, as well as carbonates interlocked with gilsonite particles more depressants is needed.

The effect of increasing the concentration of depressants on the ash content and recovery of gilsonite concentrate in the presence of kerosene collector and the MIBC frother are shown in Fig. 9. Similar to previous experiments, increasing the dosage of depressants did not significantly affect the ash content; however, the recovery of flotation in the presence of collector and frother has increased more than twice by increasing the dosage of depressant from 100 to $200 \mathrm{~g} / \mathrm{ton}$.

\section{3-3 Significance of cleaner and recleaner stages on gilsonite flotation}

In order to increase the purity and reduce the ash content in the gilsonite samples obtained from rougher flotation stage, cleaner and recleaner flotation experiments were performed on concentrate products of experiments No. 3 and 9, which were more favorable in terms of grade and recovery. As can be seen from the experiments results (Table 6), flotation in the cleaner and recleaner stages for rougher concentrate of experiment No. 9 resulted in the production of a pure concentrate with less than $5 \%$ ash content $(4.89 \%)$ and $86.75 \%$ recovery.

According to microscopic studies and liberation degree values, the size of gangue particles associated with gilsonite are variable and can be classified into two groups: coarse gangue particles with the size fraction of $100-200 \mu \mathrm{m}$, and fine particles smaller than $50 \mu \mathrm{m}$. The coarse gangue particles will be removed during the rougher flotation process due to their hydrophilic properties and will be rejected into the tailings stream. However, fine particles, most of which are smaller than $50 \mu \mathrm{m}$ and are observed in fractions smaller than $105 \mu \mathrm{m}$ interlocked with the mineral, will introduce to the rougher flotation 
concentrate (Figs. 2 and 3). Therefore, in order to liberate gilsonite particles from fine gangues and increasing the grade of the cleaner flotation stage concentrate, it is necessary to re-grind the rougher flotation concentrate. On the other hand, sulfur in gilsonite is found in both organic and inorganic (mineral) forms. The mineral sulfur is usually found in the form of iron sulfides such as pyrite, marcasite, and sometimes in the form of gypsum. This part of the sulfur will also be separated from gilsonite during the flotation process. However, organic sulfur is present in aromatic compounds in the gilsonite structure. These compounds are usually of thiophene type, but they are also observed in other forms and are chemically bonded to gilsonite. For this reason, this type of sulfur cannot be easily removed by the flotation method. Therefore, the amount of impurities left after the recleaner stage can be attributed to the organic sulfur in the gilsonite structure.

Table 6

Grade and recovery values of flotation in the cleaner and recleaner stages for concentrates of experiments No. 3 and 9

\begin{tabular}{|lllll|}
\hline Flotation stage & Recovery (\%) & Ash content (\%) & Weight \% & product \\
\hline Experiment No. 3 & & & & \\
\hline Cleaner & 93.80 & 5.72 & 88.50 & Concentrate \\
\cline { 2 - 5 } & 6.20 & 10.33 & 11.50 & Tailing \\
\cline { 2 - 5 } & 100 & 6.31 & 100 & Feed \\
\hline Recleaner & 92.30 & 5.10 & 92.07 & Concentrate \\
\cline { 2 - 5 } & 7.70 & 10.20 & 7.93 & Tailing \\
\hline Experiment No. & 100 & 5.72 & 100 & Feed \\
\hline Cleaner & 98.20 & 6.28 & 95.10 & Concentrate \\
\cline { 2 - 5 } & 1.80 & 10.93 & 4.90 & Tailing \\
\cline { 2 - 5 } & 100 & 6.51 & 100 & Feed \\
\hline Recleaner & 93.4 & 4.89 & 86.75 & Concentrate \\
\cline { 2 - 5 } & 6.60 & 15.34 & 13.25 & Tailing \\
\cline { 2 - 5 } & 100 & 6.28 & 100 & Feed \\
\hline & & & & \\
\hline
\end{tabular}

\section{3-4 Suggested flowsheet for production ultra-low-ash (<5\%) gilsonite}

Based on the chemical and mineralogical characterisation of the sample and the results of processing experiments, a flowsheet has been proposed to produce a low ash gilsonite concentrate (Fig. 10). For this purpose, after the initial crushing of the ore extracted from the mine, the milling process will be carried out by a rod mill (due to the production of a product with a higher degree of liberation) in a closed circuit with 
a hydrocyclone with a cut-size of $250 \mu \mathrm{m}$. Hydrocyclone overflow is the feed to the rougher stage flotation cells. The concentrate of rougher passes the second hydrocyclone and the tailing goes to the final tailings tank. The cut-size of the second hydrocyclone is $100 \mu \mathrm{m}$, of which particles larger than this are transferred to the ball mill for re-grinding and the liberation of gilsonite particles from fine gangues (less than $50 \mu \mathrm{m}$ in size). The hydrocyclone overflow, which contains particles smaller than $100 \mu \mathrm{m}$ in size, enters the cleaner flotation cells. The cleaner stage tail is feed to scavenger flotation cells and its concentrate is feed to recleaner cells. Finally, the recleaner concentrate is transferred to the final concentrate tank and its tailings, along with the scavenger concentrate, are back to feed the cleaner stage. Scavenger tailing is also transferred to rougher cells feed.

\section{Conclusion}

The efficiency of gilsonite flotation, like other minerals, is affected by the type and dosage of chemical reagents used during this process. Due to the high hydrophobic properties of gilsonite and performed flotation experiments, it can be concluded that the flotation process of this material does not require a collector. However, in order to increase the recovery of gilsonite, the use of $400 \mathrm{~g} /$ ton kerosene and 100 $\mathrm{g} /$ ton gas oil as collectors and MIBC as frother has led to the production of a concentrate with more than $80 \%$ recovery in gilsonite flotation. On the other hand, high concentrations of depressants are required to depress impurities and ash-removal to the desired level. Using a depressant with a concentration greater than $200 \mathrm{~g} /$ ton has a greater influence on reducing the ash content of gilsonite concentrate than not using them. In general, flotation experiments under different conditions indicate that only mineral impurities associated with gilsonite have been removed by the flotation method and flotation has no effect on organic impurities. Finally, according to the aim of the research to produce a concentrate with less than $5 \%$ ash, flotation experiments in rougher, cleaner and recleaner stages led to the production of a concentrate with less than $5 \%$ ash $(4.89 \%)$ and recovery of $86.75 \%$. Also gilsonite flotation tailings can be used in common gilsonite applications such as asphalt, bituminous waterproofing application, etc., due to their particle size and ash content.

\section{Declarations}

\section{Author contributions}

Ataallah Bahrami: Idea of research

Fatemeh Kazemi: perform test and provide report and write the article

MirSaleh Mirmohammadi: mineralogical study

Yousef Ghorbani: provide report and Idea about test 


\section{References}

1. Helms, J., Kong, X., Salmon, E. \& Hatcher, P. Structural characterization of Gilsonite bitumen by advance nuclear magnetic resonance spectroscopy and ultrahigh resolution mass spectrometry revealing Pyrrolic and aromatic rings substituted with aliphatic chains. Journal of organic Geochemistry. 44, 21-36 (2012).

2. Nciri, N., Song, S., Kim, N. \& Cho, N. Chemical characterization of gilsonite bitumen. Journal of Petroleum \& Environmental Biotechnology. 5 (5), 1 (2014).

3. Bahrami, A., Kazemi, F. \& Ghorbani, Y. Effect of different reagent regime on the kinetic model and recovery in gilsonite flotation. Journal of materials research and technology. 8 (5), 4498-4509 (2019).

4. Carr, Donald, D. Industrial Mineral and Rocks, six edition vol1, sonior editor, pp 535-543(1994).

5. Mirhabibi, A. R. et al. F., \& Characterization of some new Iranian bitumen(2001).

6. Erol, M., Colduroglu, C. \& Aktas, Z. The effect of reagents and reagent mixtures on froth flotation of coal fines. International journal of mineral processing. 71 (1-4), 131-145 (2003).

7. Cebeci, Y. The Investigation of the Floatability Improvement of Yozgat Ayridam Lignite Using Various Collectors. Fuel. 81 (3), 281-289 (2002).

8. Kazemi, F. Site selection of gilsonite ore dressing plant, based on industrial specification of mine (Kermanshah). Master of Science Thesis in Mining Engineering, Urmia University, Iran(2017).

9. Kazemi, F., Bahrami, A. \& Abdolahi Sharif, J. Mineral processing plant site selection using integrated fuzzy cognitive map and fuzzy analytical hierarchy process approach: A case study of gilsonite mines in Iran. Minerals engineering. 147, 106-143 (2020).

10. Bahrami, A., Kazemi, F., Ghorbani, Y. \& Abdolahi Sharif, J. The Order of Kinetic Models, Rate Constant Distribution, and Maximum Combustible Recovery in Gilsonite Flotation. Society for Mining, Metallurgy \& Exploration Inc.1101-1114(2019).

\section{Figures}




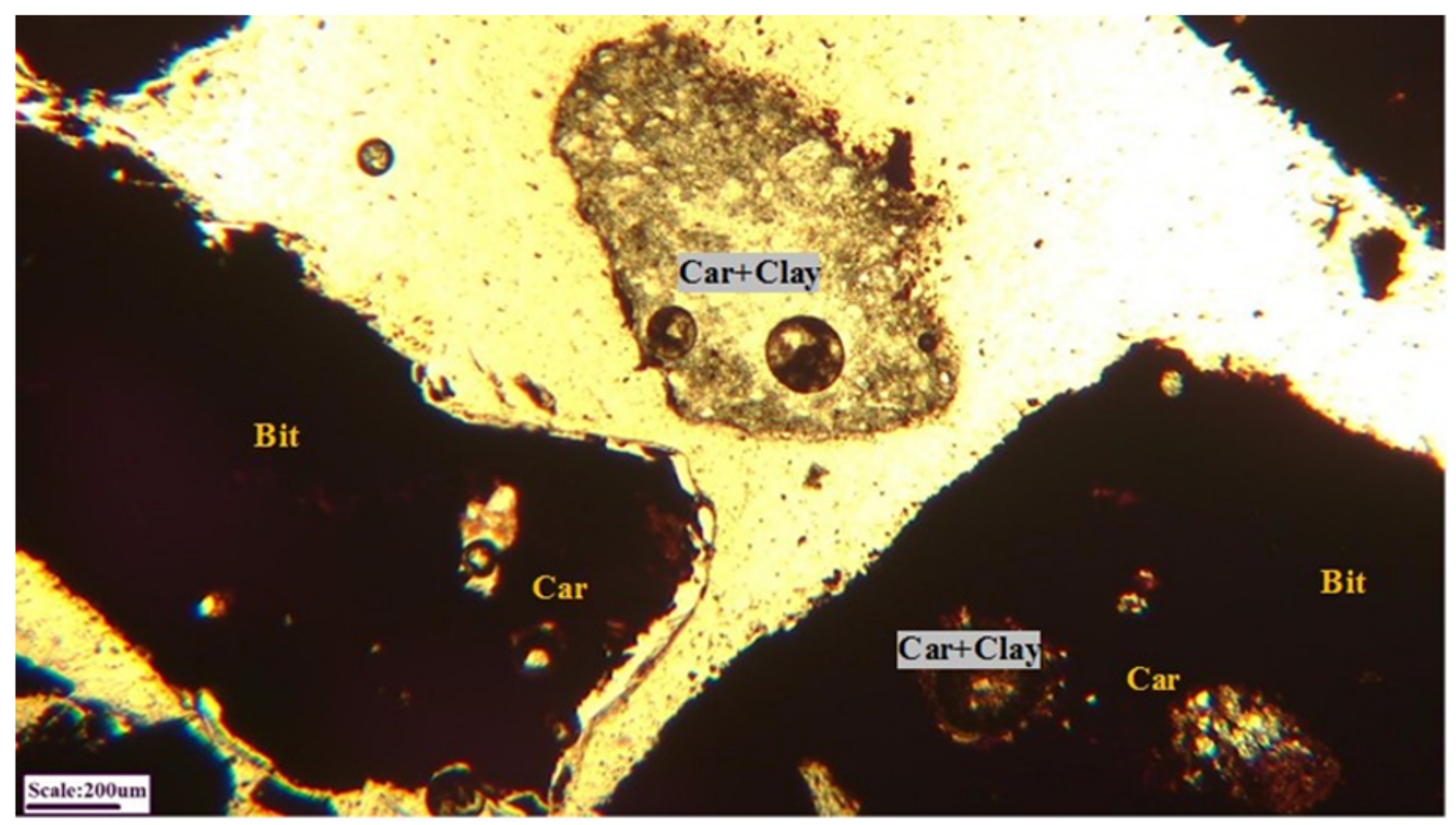

\section{Figure 1}

Microphotograph of interlocking between bitumen (Bit) and carbonate (Car) and clay minerals - in plane polarized light (PPL) 


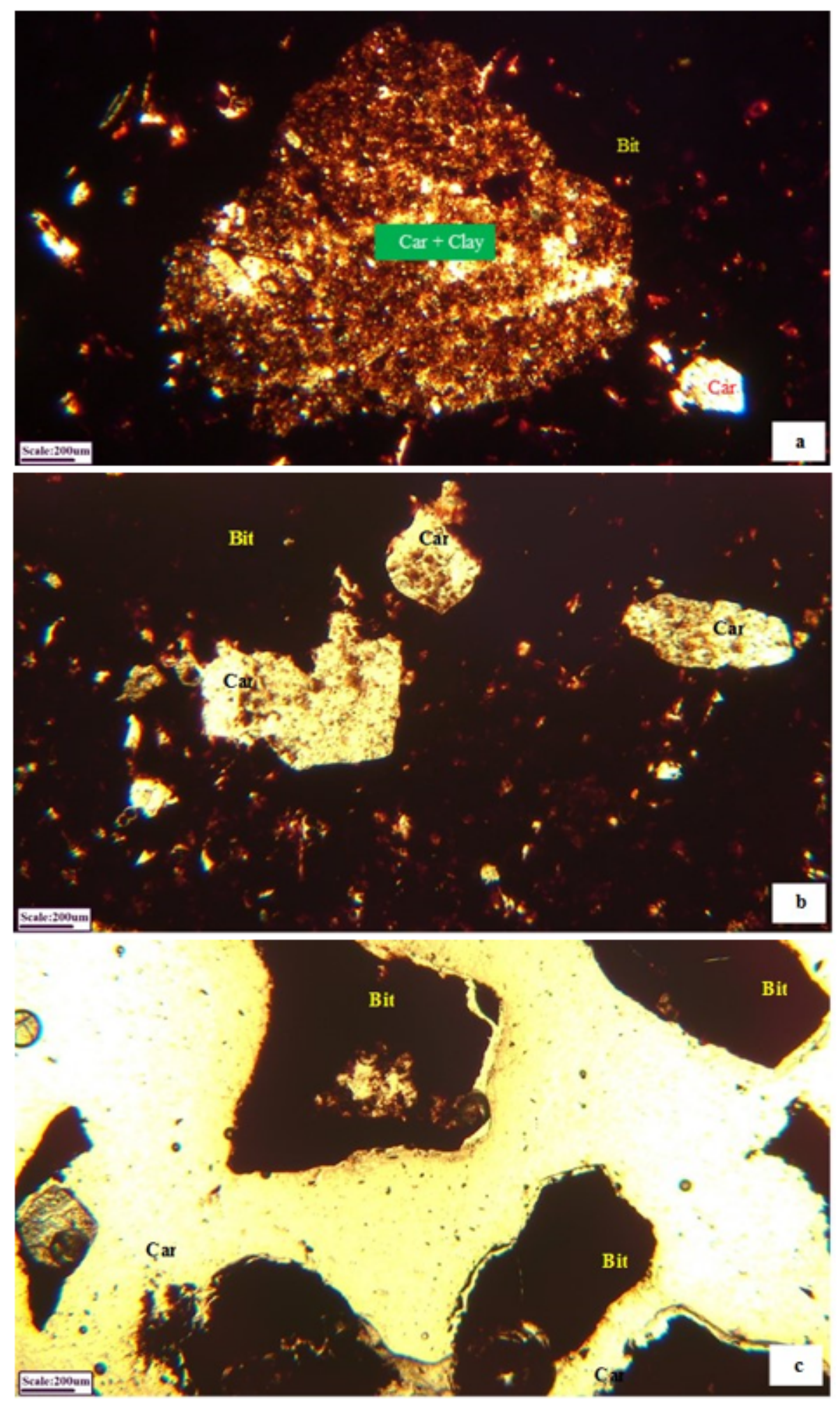

Figure 2

Distribution and abundance of gangue minerals with bitumen in the size fraction of a) coarse particles $(+3 \mathrm{~mm})$, b) medium size (+0.5 -3 mm) and c) fine particles (-1 mm) - (bitumen (Bit), carbonate (Car), clay (clay)) - microphotographs in plane polarized light (PPL) 


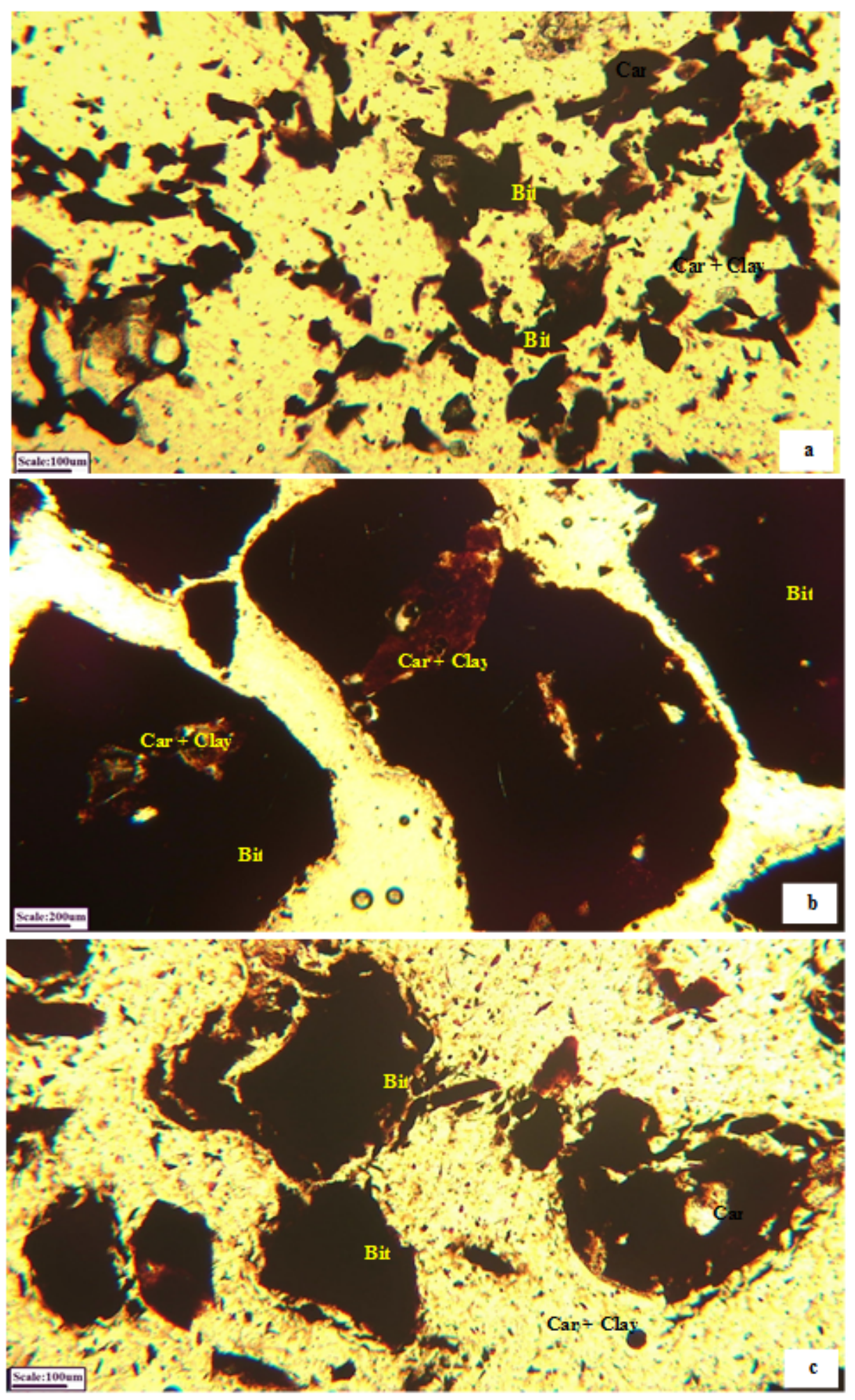

Figure 3

a) Carbonate minerals (Car) in scattered and cracks filling forms and gangue distribution in -105 $\mu \mathrm{m}$ fraction, b) interlocking of minerals, and c) gilsonite distribution in the 105-420 $\mu \mathrm{m}$ factions - (bitumen (Bit), carbonate (Car), clay (clay)) - microphotographs in plane polarized light (PPL) 


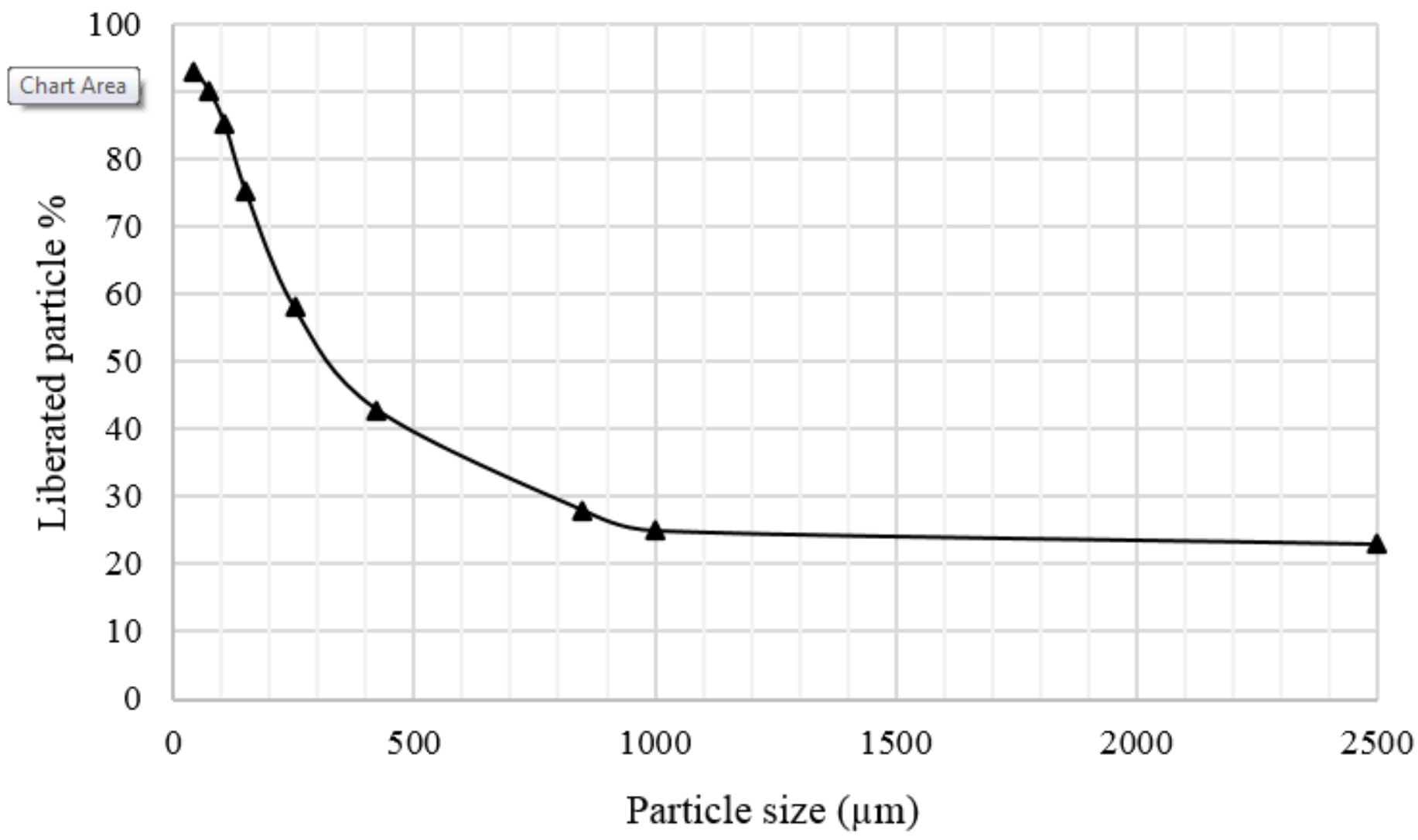

Figure 4

Graph of gilsonite liberation degree in terms of particle size in different particle size fractions

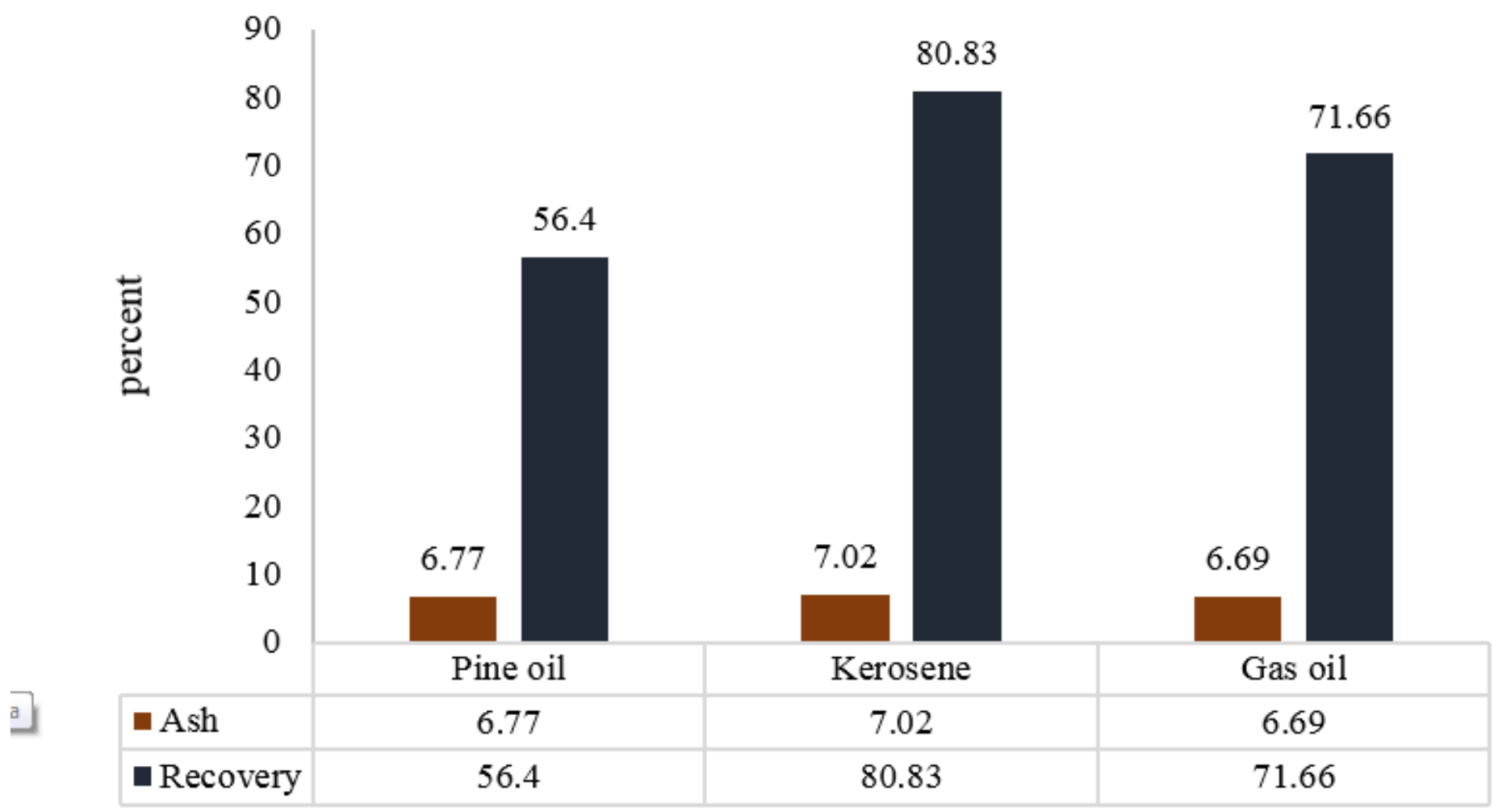


Figure 5

Ash content and recovery of gilsonite rougher flotation concentrate under the conditions of using pine oil, kerosene and gas oil collectors
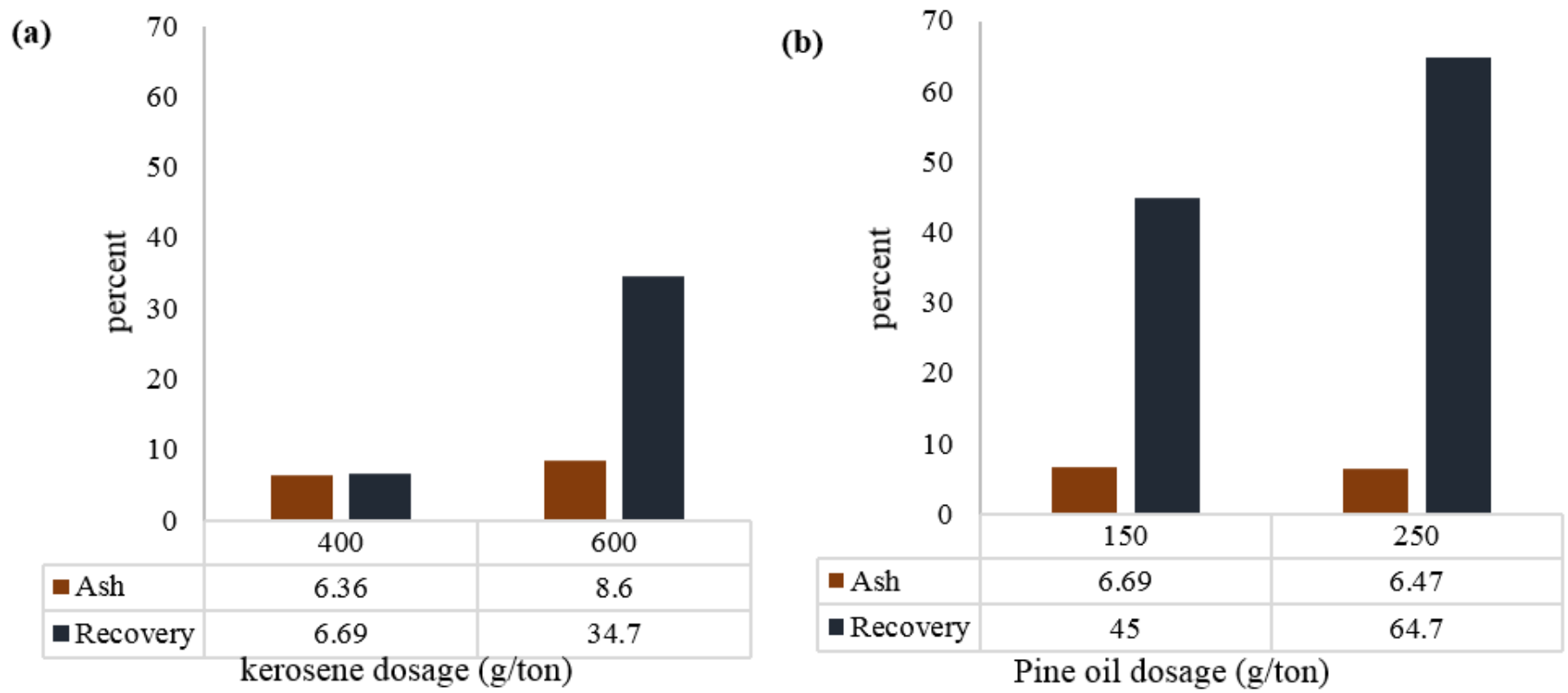

\section{Figure 6}

Diagrams of ash content and recovery of gilsonite flotation concentrate at concentrations of a) 400 and $600 \mathrm{~g} /$ ton of kerosene collector and b) 150 and $250 \mathrm{~g} /$ ton of pine oil collector.

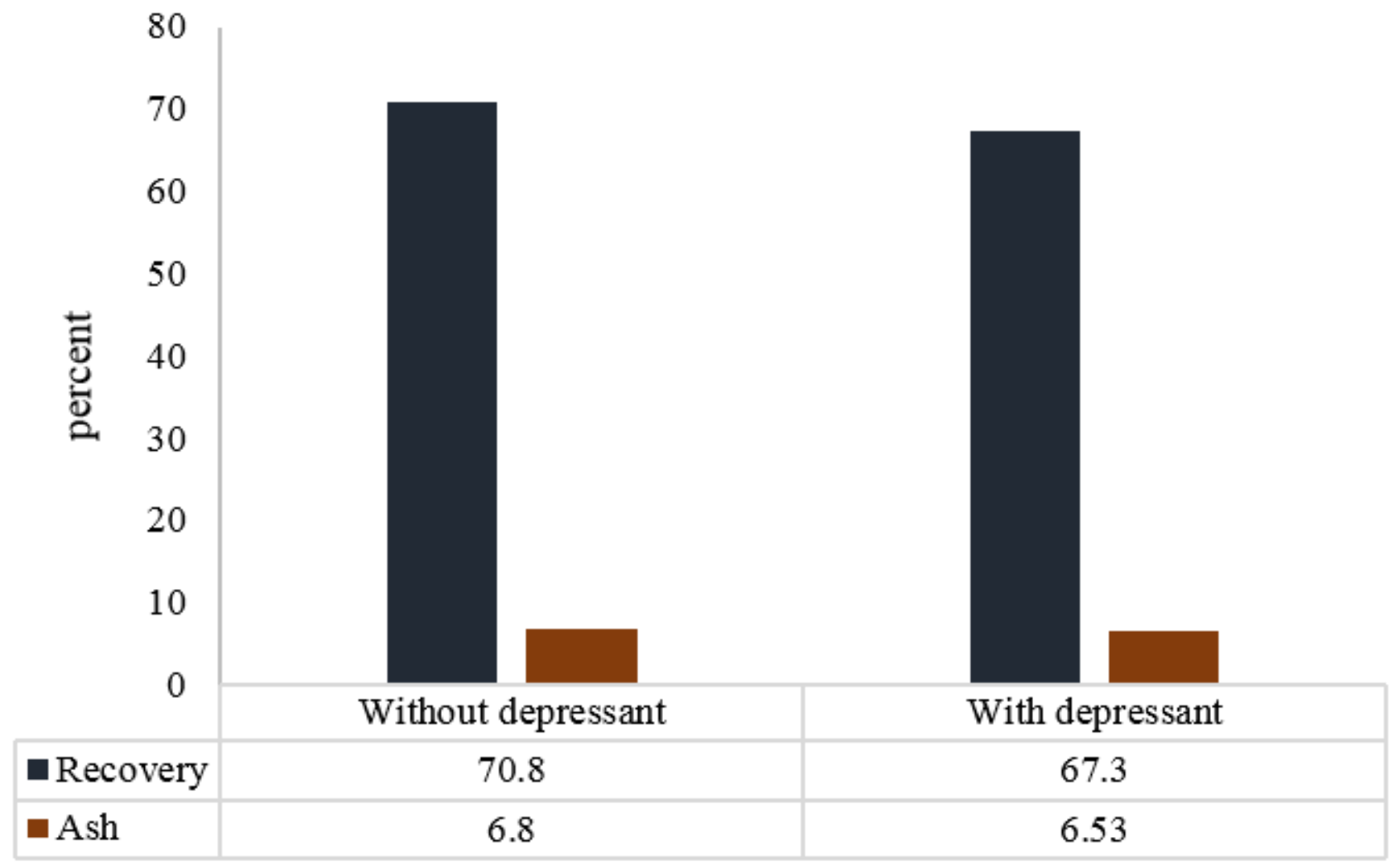


Figure 7

Recovery and ash content of gilsonite flotation concentrate in the presence and absence of the depressants (without collector and frother)

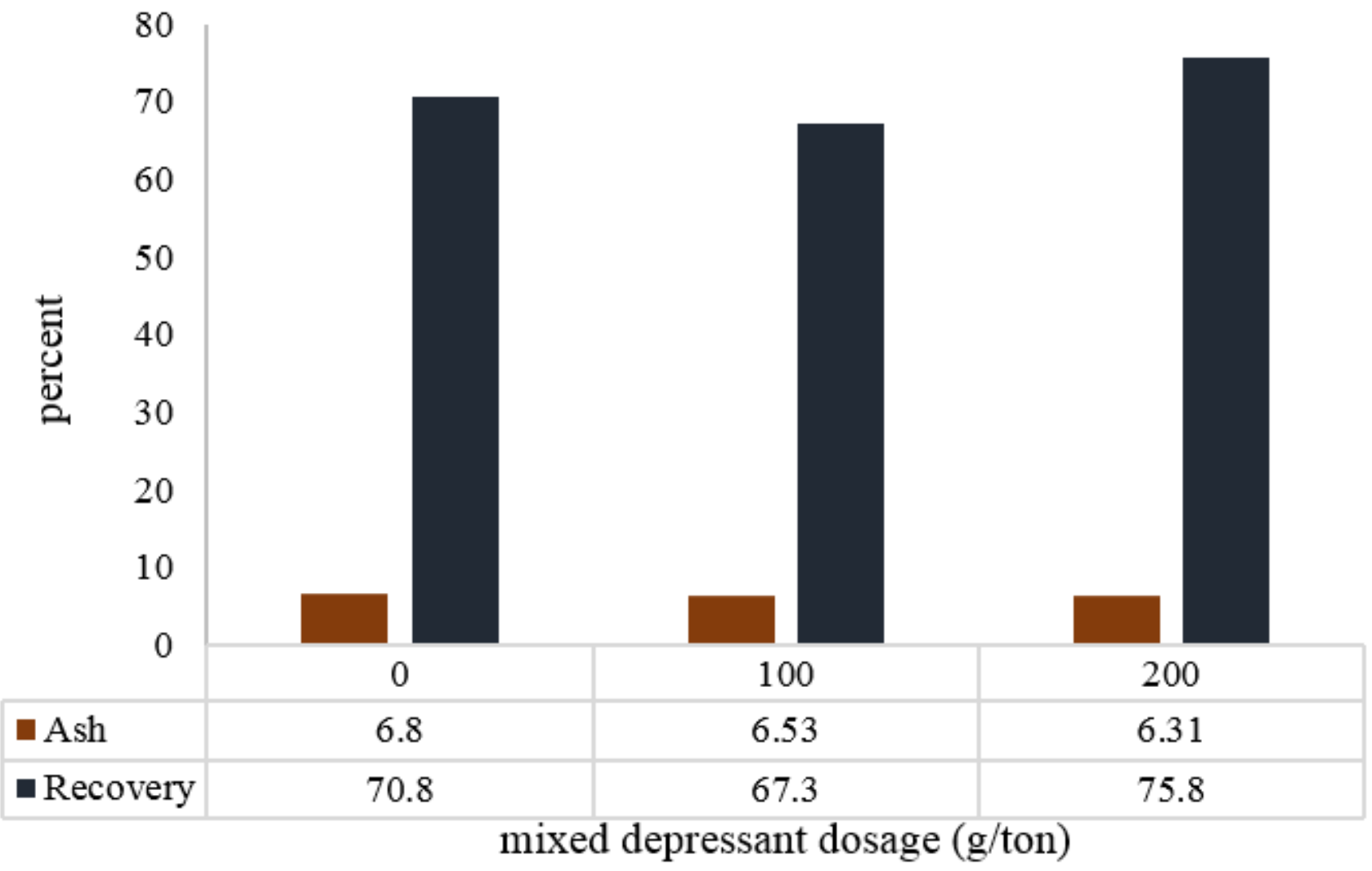

\section{Figure 8}

Recovery and ash of gilsonite flotation concentrate in the presence depressant (absence of collector and frother) 


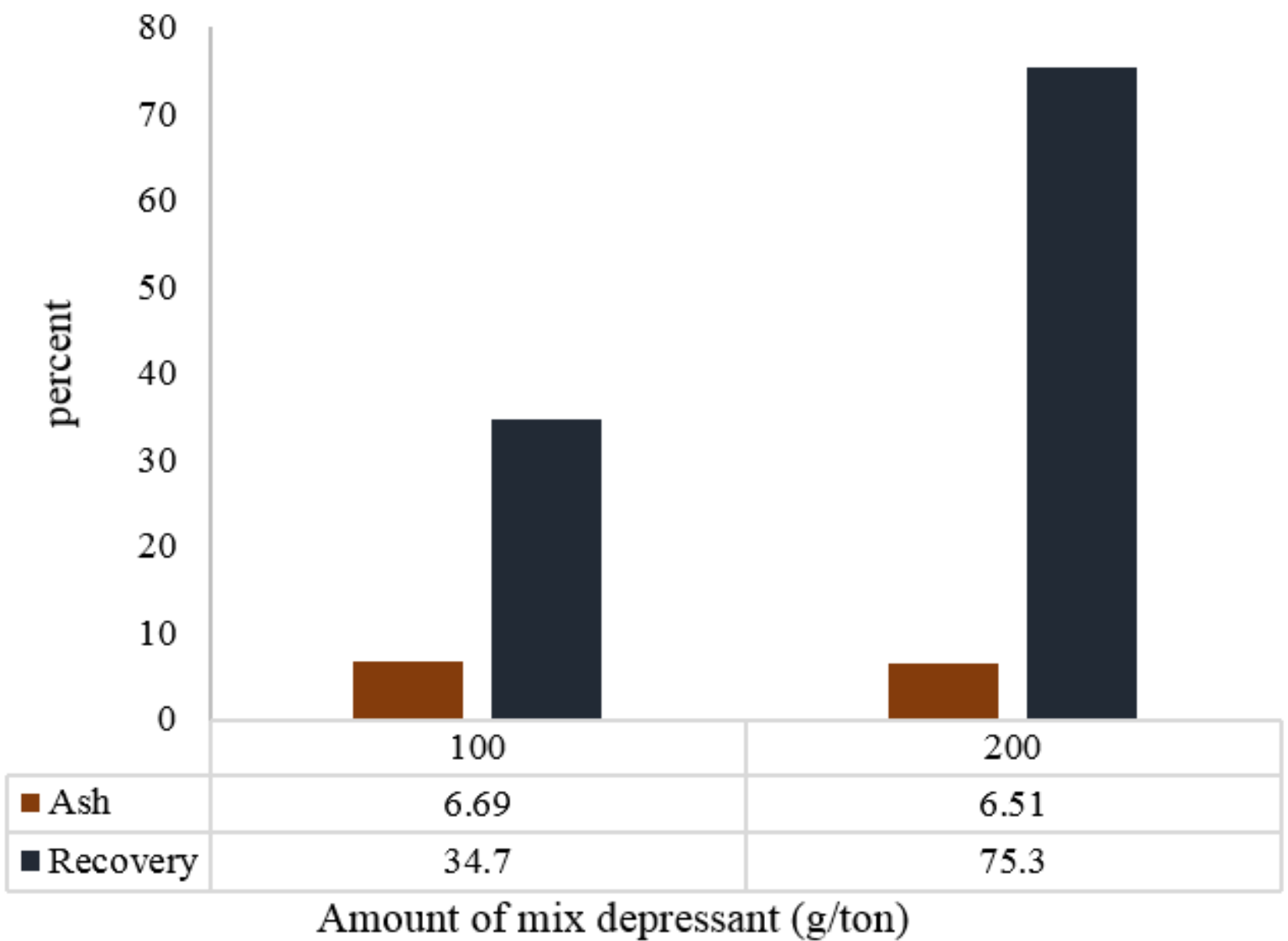

Figure 9

Effect of increasing depressant concentration on gilsonite flotation in the presence of kerosene and MIBC 


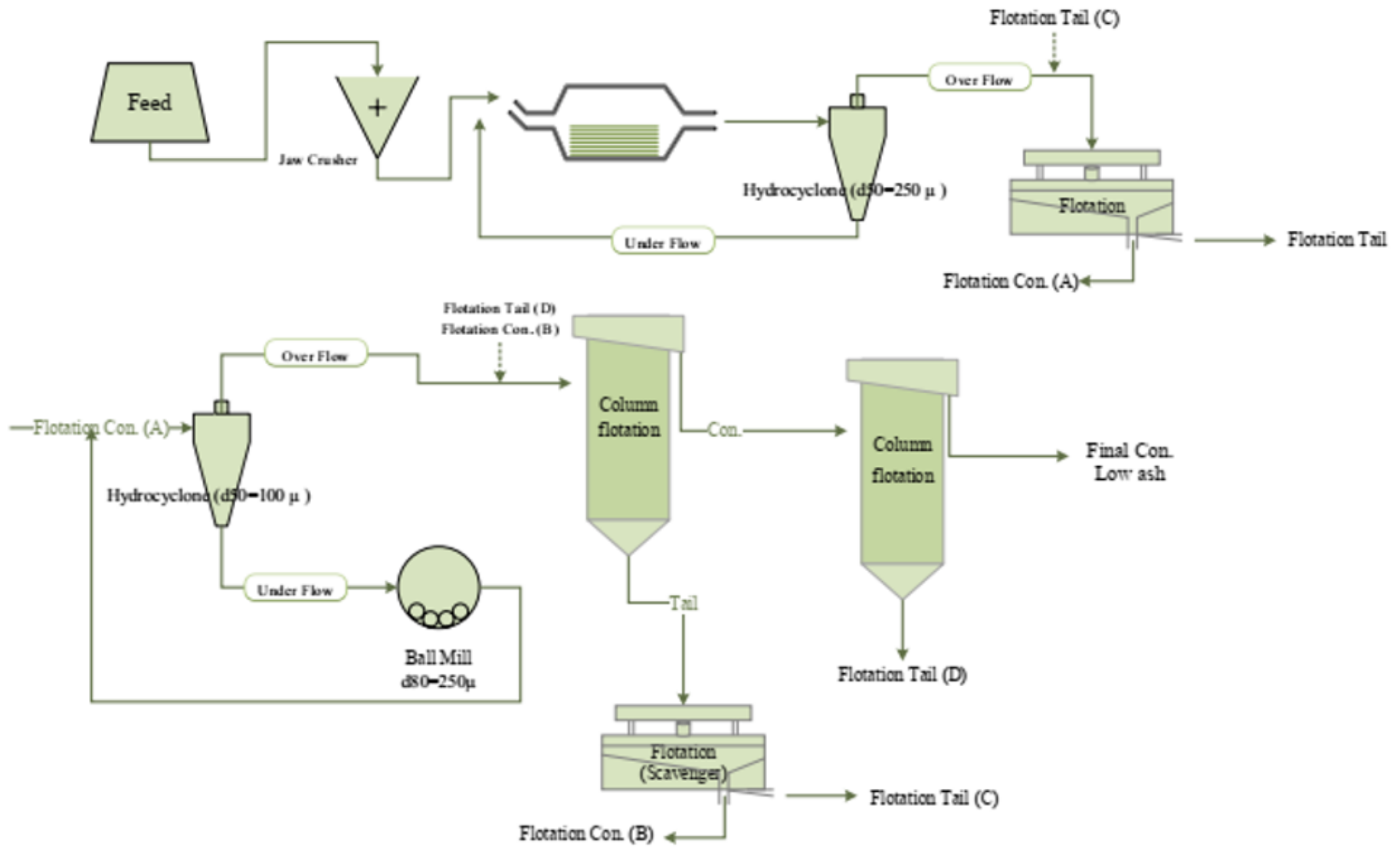

Figure 10

Gilsonite flotation circuit flowsheet for the production of ultra-low ash gilsonite 